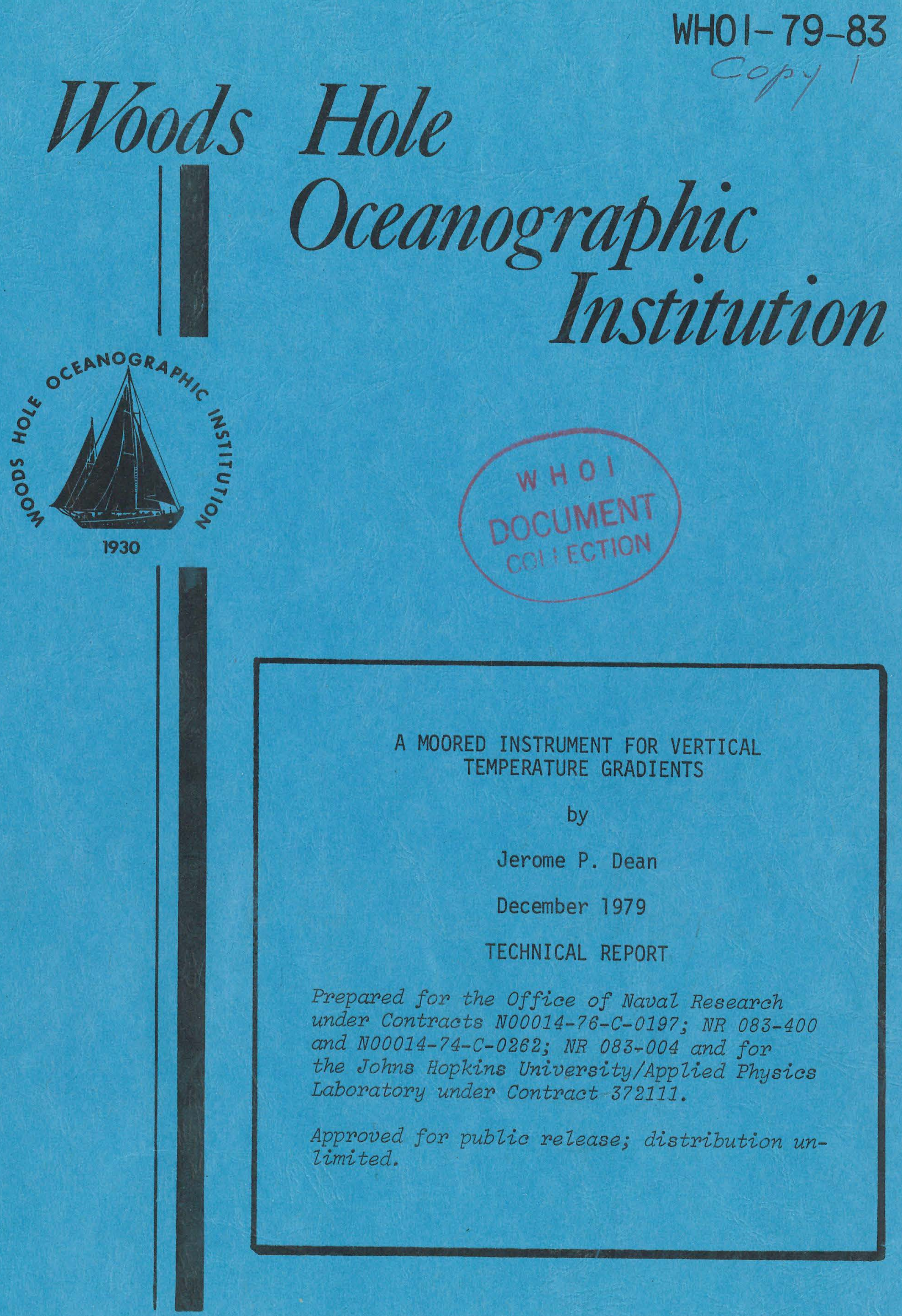

WOODS HOLE, MASSACHUSETTS 02543 
WHOI-79-83

A MOORED INSTRUMENT FOR VERTICAL TEMPERATURE GRADIENTS

by

Jerome P. Dean

WOODS HOLE OCEANOGRAPHIC INSTITUTION

Woods Hole, Massachusetts 02543

December 1979

TECHNICAL REPORT

Prepared for the Office of Naval Research under Contracts N00014-76-C-0197; NR 083-400 and N00014-74-C-0262; NR 083-004 and for the Johns Hopkins University/Applied Physics Laboratory under Contract 372111.

Reproduction in whole or in part is permitted for any purpose of the United States Govermment. In citing this report in a bibliography, the reference given should be to the "Journal of Geophysical Research, Vol. 84, No. C8, August 20, 1979, pp. 5089-5091".

Approved for public release; distribution unimited.

Approved for Distribution: Valentine Worthington, Chairman Department of Physical Oceanography 


\title{
A Moored Instrument for Vertical Temperature Gradients
}

\author{
JEROME P. DEAN \\ Woods Hole Oceanographic Institution, Woods Hole, Massachusetts 02543
}

\begin{abstract}
Vector averaging current meters have been modified to measure the temperature gradient in addition to current and absolute temperature. The modified instrument measures the temperature difference between sensors spaced vertically $1.74 \mathrm{~m}$ apart (or closer) using thermistors in a Wheatstone bridge circuit. Calibrations provide corrections for drift and static offset resulting in temperature gradient measurements accurate to about $0.5 \mathrm{~m}{ }^{\circ} \mathrm{C} / \mathrm{m}$. Originally developed to infer vertical velocities, the instrument has also been successfully used to study mixed layer motions and thickness variations and to investigate temperature fine structure.
\end{abstract}

\section{INTRODUCTION}

In October and early November 1973, members of the Woods Hole Oceanographic Institution (WHOI) Buoy Group set a three-legged stable mooring west of Bermuda in the Sargasso Sea in an internal wave experiment (lwex) [Moller, 1974; Briscoe, 1975]. The mooring supported a variety of scientific and engineering instruments including 17 vector averaging current meters (VACM). One purpose of the threedimensional moored array was to observe variations in the temperature field in the main thermocline; to supplement these observations, we developed a new instrument especially to measure and record the temperature gradient. Data from these instruments and others on the mooring have been used to construct a three-dimensional time series of water motion [Briscoe, 1975; Müller et al., 1978].

Although the original motivation for the temperature gradient instrumentation was the estimation of vertical velocities, other uses are possible. For example, Joyce and Desaubies [1977] have shown that the temperature difference data can be used to help discriminate between temperature fine structure and internal waves.

In 1977 the differential temperature VACM's (DTVACM's) were used to monitor the height of the deep ocean bottom mixed layer by detecting the absence of temperature gradients and fine structure in the mixed layer. The time series of Figure 1 are from six DT-VACM's at $10-\mathrm{m}$ vertical spacing starting $15 \mathrm{~m}$ off the bottom for an 8-day segment of a 3month experiment, WHOI moored station 621 (L. Armi, personal communication, 1977). Presence of the mixed layer is characterized by periods of near-zero temperature difference, while at other times the records show a fluctuating signal produced by the fine structure and the larger temperature step which exists at the top of the mixed layer [Armi and Millard, 1976]. Variations in the thickness of the deep mixed layer are clearly evident from these records. A similar mixed layer detection scheme with DT.VACM's was used in the Baltic Sea in 1975 for near-surface measurements (W. Zenk, personal communication, 1975).

There have been other uses of the DT-VACM's which blend the vertical motion and fine structure detection capabilities of the instrument (WHOI moored station 615 (M. Briscoe, personal communication, 1978) and during the Joint Air-Sea Interaction Project (Pollard [1978]; see 'w' moorings, Figure 4)). The purpose of this note is to make the DT.VACM and its capabilities known to other potential users.

Copyright (C) 1979 by the American Geophysical Union.

\section{INSTRUMENT}

The VACM since 1972 has been used at the Woods Hole Oceanographic Institution to measure currents in the deep ocean. Having been designed with recording flexibility and space for additional circuitry, the VACM was therefore a convenient instrument to modify for measuring and recording the temperature gradient [McCullough, 1975].

To obtain highly accurate $\left(0.5 \mathrm{~m}{ }^{\circ} \mathrm{C} / \mathrm{m}\right)$ data, a differential measurement over an appropriate spatial interval was made rather than subtracting two absolute temperatures. Thermistors were chosen as the primary sensor for the measurement because of experience with these devices and the fact that by 1973 techniques for accelerated aging and stability testing had been developed which effectively reduced the uncertainty due to thermistor drift to less than $0.1 \mathrm{~m}^{\circ} \mathrm{C}$ per month.

External pressure housings or pods for the thermistors were attached to the VACM with a vertical separation of $174 \mathrm{~cm}$ (Figure 2); the pods can be moved closer together if desired.

The thermistors are two legs of a Wheatstone bridge; the output is a function of the temperature difference between the sensors. This signal is amplified and converted to pulses which are stored in a counter and correspond to the temperature difference of the sensors over a range of $\pm 500 \mathrm{~m}{ }^{\circ} \mathrm{C}$.

\section{CALIBrations}

Each temperature sensor was stabilized by temperature cycling and tested for stability by repeated calibrations at regular intervals. Those acceptable displayed small random variation in the calibrations with little tendency to drift.

Matched sensor pairs with characteristic curves coincident within $10 \mathrm{~m}^{\circ} \mathrm{C}$ over the range of $0^{\circ}-15^{\circ} \mathrm{C}$ were selected. The absolute standard for the calibrations is a platinum thermometer traceable to the National Bureau of Standards. Total systematic errors in this standard are estimated to be less than $2 \mathrm{~m}$ ${ }^{\circ} \mathrm{C}$, and random errors in the calibrations are less than $2.5 \mathrm{~m}$ ${ }^{\circ} \mathrm{C}$ (2 sigma) (A. Bradshaw, personal communication, 1977).

The sensor pods are immersed side by side in a well-mixed constant temperature bath and tested at three temperatures $\left(5^{\circ}, 10^{\circ}\right.$, and $\left.15^{\circ} \mathrm{C}\right)$ for systems tests before and after the field experiment.

\section{ERRORS AND CORRECTIONS}

For our purposes, drift is the difference in the before and after system calibrations, and bias is the difference between thermistor calibrations and the system calibrations. A bias correction is necessary because individual thermistor constants are used in the data reduction and calibration errors accumulate in the process; there are also small errors from the circui- 


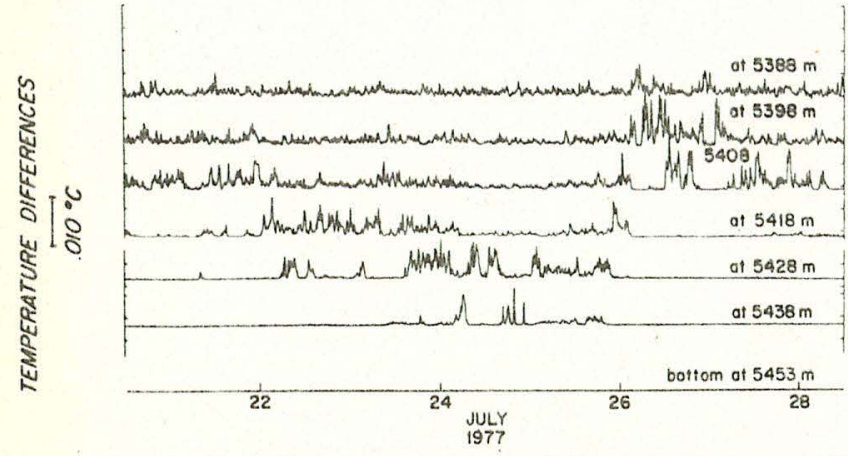

Fig. 1. Time series of temperature differences from six DTVACM's at station 621. Note periods of near-zero gradient contrasted with fine structure signals as the depth of the mixed layer changes.

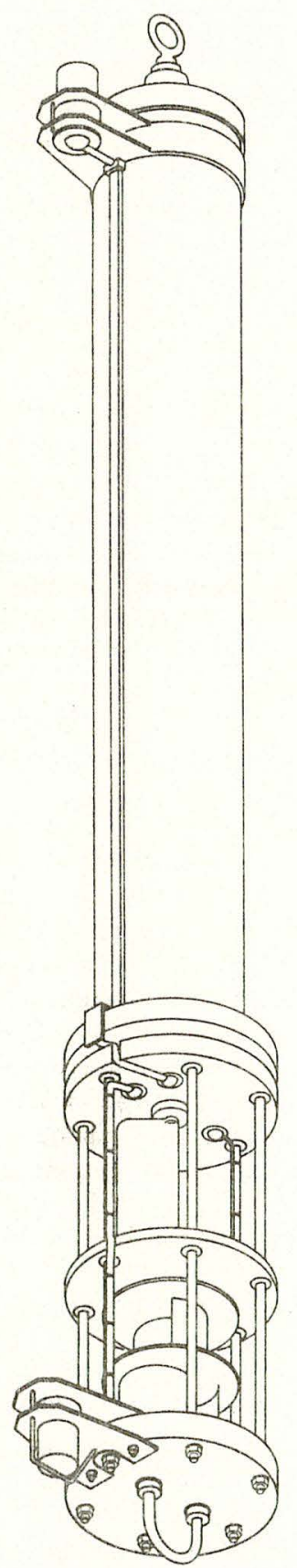

Fig. 2. Modified VACM showing the thermistor pods at the two ends with vertical spacing of $1.74 \mathrm{~m}$.

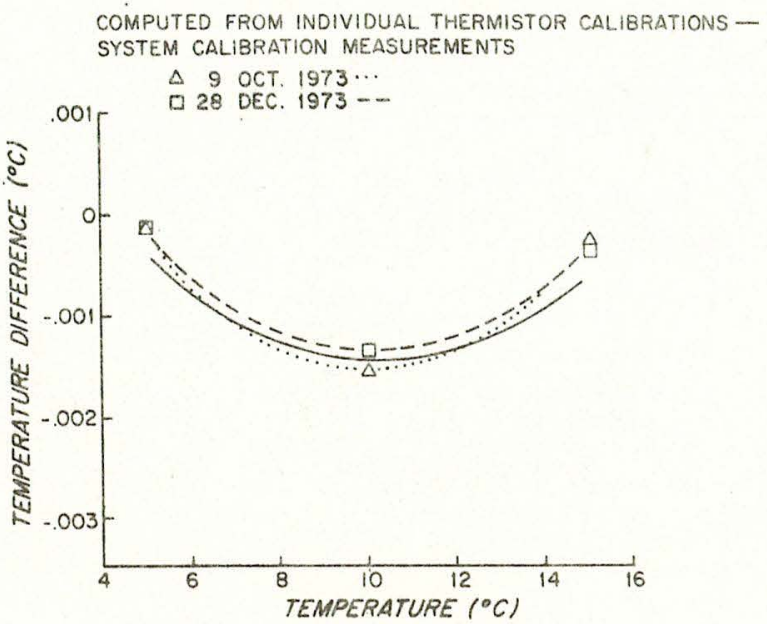

Fig. 3. Zero temperature difference characteristic curve for VACM record 515-B4 (Iwex).

try. By making these two adjustments to the data we can get a precision in the difference measurement of about $0.5 \mathrm{~m}^{\circ} \mathrm{C}$.

Figures 3 and 4 are zero temperature difference characteristics of two representative sets of matched pairs used in Iwex. Prelaunch and postrecovery calibration data from both individual thermistor and system calibrations are shown.

We estimate an uncertainty of $0.2 \mathrm{~m}^{\circ} \mathrm{C}$ for the zero difference bath calibrations based on repeated calibrations and data from one instrument which was tested at all test positions.

The spectrum of noise data taken during laboratory calibrations in the constant temperature bath appears white at an average energy level of $10-7^{\circ} \mathrm{C} / \mathrm{cph}$. The spectrum of a quiet period in the deep mixed layer has an average energy level of $10^{-10}{ }^{\circ} \mathrm{C} / \mathrm{cph}$ and is an indication that the bath noise is ther$\mathrm{mal}$ and not instrumental. The lab tests also demonstrated the stability of the calibration bath, since the absolute temperature
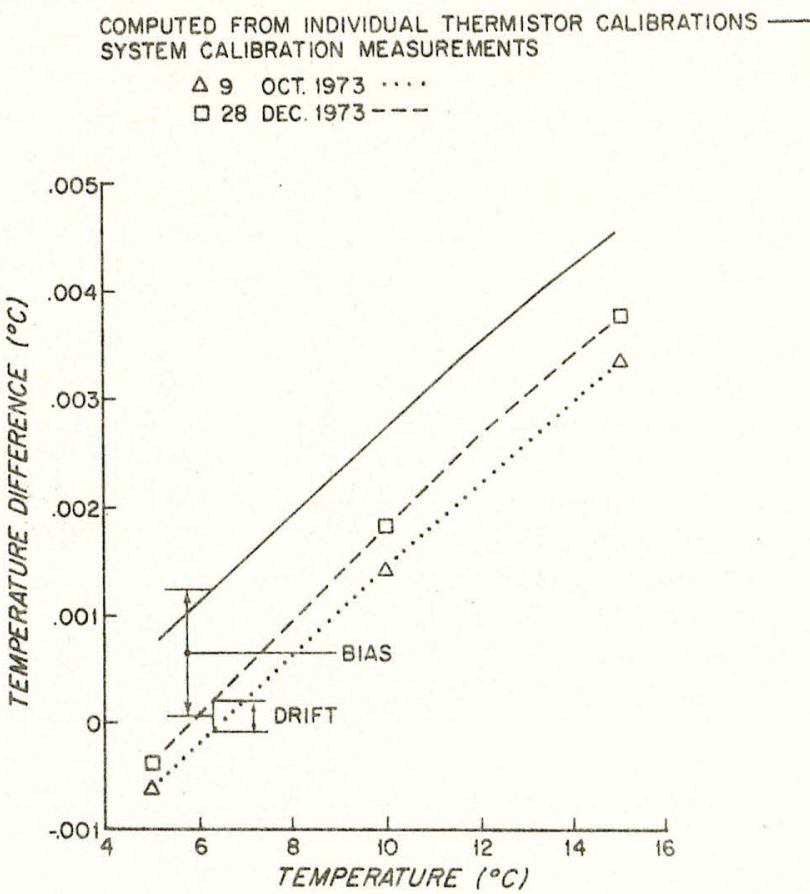

Fig. 4. Zero temperature difference characteristic curve for VACM record 515-C10 (Iwex). 
measuring circuit, averaged over $225 \mathrm{~s}$, recorded the bath temperature stable to within \pm 1 data count, or $0.16 \mathrm{~m}^{\circ} \mathrm{C}$. This system bath calibration also makes possible a bias correction in the absolute temperature measurement. With this correction the absolute accuracy is estimated to be about $3 \mathrm{~m}^{\circ} \mathrm{C}$ with an additional $2 \mathrm{~m}^{\circ} \mathrm{C}$ uncertainty in our standard (total systematic error). This result indicates that the errors in summing two absolute temperatures for the gradient could have been as much as an order of magnitude higher than those we get with the differential measurement.

Acknowledgments. The DT-VACM's were initially developed as part of the Iwex work, which was sponsored primarily by the Applied Physics Laboratory of the Johns Hopkins University, contract 372111 additional support has been received from the Office of $\mathrm{Naval} \mathrm{Re}$ search via contract N00014-74-C-0262, NR 983-004, and contract N00014-76-C-0197, NR 083-400. Credit for the circuits and algorithms belongs to R. Koehler, C. Hardy, and J. McCullough; special thanks to J. Poirier, our current meter shop supervisor, and to Mel Briscoe. This is WHOI contribution 3828.

\section{REFERENCES}

Armi, L., and R. C. Millard, Jr., The bottom boundary layer of the deep ocean, J. Geophys. Res., 81(27), 4983-4990, 1976.

Briscoe, M., Preliminary results from the trimoored internal wave experiment (Iwex), J. Geophys. Res., 80(27), 3872-3884, 1975.

Joyce, T. M., and Y.J.F. Desaubies, Discrimination between internal wayes and temperature finestructure, J. Phys. Oceanogr., 7(1), 22$32,1977$.

McCullough, J. R., Vector averaging current meter speed calibration and recording technique, Tech. Rep. WHOI-75-44, Woods Hole Oceanogr. Inst., Woods Hole, Mass., 1975.

Moller, D. A., Knorr 34, October 13 to November 8, 1973, and Knorr 36, December 6 to 22, 1973, Tech. Rep. WHOI-74-94, Woods Hole Oceanogr. Inst., Woods Hole, Mass. 1974

Müller, P., D. J. Olbers, and J. Willebrand, The Iwex spectrum, $J$. Geophys. Res., 83(C1), 479-500, 1978.

Pollard, R. T., The joint air-sea interaction experiment-JASIN 1978 , Bull. Amer. Meteorol. Soc., 59(10), 1310-1318, 1978.

(Received February 14, 1979:

revised February 15, 1979;

accepted February 15, 1979.) 
FOR UNCLASSIFIED TECHNICAL REPORTS, REPRINTS, AND FINAL REPORTS

PUBLISHED BY OCEANOGRAPHIC CONTRACTORS

OF THE OCEAN SCIENCE AND TECHNOLOGY DIVISION

OF THE OFFICE OF NAVAL RESEARCH

(REVISED NOVEMBER 1978)

1 Deputy Under Secretary of Defense

(Research and Advanced Technology)

Military Assistant for Environmental Science Room 3D129

Washington, D.C. 20301

Office of Naval Research

800 North Quincy Street

Arlington, VA 22217

3 ATTN: Code 483

1 ATTN: Code 460

2 ATTN: 102B

1 CDR J. C. Harlett, (USN)

ONR Representative

Woods Hole Oceanographic Inst.

Woods Hole, MA 02543

Commanding Officer

Naval Research Laboratory

Washington, D.C. 20375

6 ATTN: Library, Code 2627
12 Defense Documentation Center Cameron Station

Alexandria, VA 22314

ATTN: DCA

Commander

Naval Oceanographic Office NSTL Station

Bay St. Louis, MS 39522

1 ATTN: Code 8100

1 ATTN: Code 6000

1 ATTN: Code 3300

$1 \quad$ NODC/NOAA

Code D781

Wiscons in Avenue, N.W.

Washington, D.C. 20235 


\section{UNCLASSIFIED $\quad 12 / 79$}

SECURITY CLASSIFICATION OF THIS PAGE (WhON Date Enterod)

\begin{tabular}{|c|c|}
\hline REPORT DOCUMENTATION PAGE & $\begin{array}{l}\text { READ INSTRUCTIONS } \\
\text { BEFORE COMPLETING FORM }\end{array}$ \\
\hline $\begin{array}{l}\text { 1. REPORT NUMBER } \\
\text { WHOI }-79-83\end{array}$ & 3. RECIPIENT'S CATALOG NUMBER \\
\hline \multirow{2}{*}{$\begin{array}{l}\text { 4. TITLE (and Subtitle) } \\
\text { A MOORED INSTRUMENT FOR VERTICAL TEMPERATURE } \\
\text { GRADIENTS }\end{array}$} & $\begin{array}{l}\text { 5. TYPE OF REPORT \& PERIOD COVERED } \\
\text { Technical }\end{array}$ \\
\hline & $\begin{array}{l}\text { 6. PERFORMING ORG. REPORT NUMBER } \\
\text { WHOI CON. NO. } 3828 \\
\end{array}$ \\
\hline $\begin{array}{l}\text { 7. AUTHOR(0) } \\
\text { Jerome P. Dean }\end{array}$ & $\begin{array}{l}\text { 8. CONTRACT OR GRANT NUMBER(a) } \\
\text { APL/JHU 372111 } \\
\text { N00014-76-C-0197; } \\
\text { N00014-74-C-0262: }\end{array}$ \\
\hline $\begin{array}{l}\text { 9. PERFORMING ORGANIZATION NAME AND ADDRESS } \\
\text { Woods Hole Oceanographic Institution } \\
\text { Woods Hole, MA } 02543\end{array}$ & $\begin{array}{l}\text { 10. PROGRAMELEMENT, PROJECT, TASK } \\
\text { AREA Q WORK UNIT NUMBERS } \\
\text { NR } 083-400 \\
\text { NR } 083-004\end{array}$ \\
\hline \multirow{4}{*}{$\begin{array}{l}\text { 11. CONTROLLING OFFICE NAME AND ADDRESS } \\
\text { NORDA } \\
\text { National Space Technology Laboratory } \\
\text { Bay St Luif MS } 39529 \\
\text { 14. MONITORING AGENCY NAME CADDRESS(It dlfferent from Controlline Ofllce) }\end{array}$} & $\begin{array}{l}\text { 12. REPORT DATE } \\
\text { December } 1979 \\
\end{array}$ \\
\hline & 13. NUMBER OF PAGES \\
\hline & $\begin{array}{l}\text { 15. SECURITY CLASS. (of thie sopost) } \\
\text { Unclassified }\end{array}$ \\
\hline & $\begin{array}{l}\text { 15a. DECLASSIFICATION/DOWNGRADING } \\
\text { SCHEDULE }\end{array}$ \\
\hline
\end{tabular}

16. DISTRIBUTION STATEMENT (of this Roport)

Approved for public release; distribution unlimited.

17. DISTRIBUTION STATEMENT (ol the abstract entored in Block 20, if different from Roport)

18. SUPPLEMENTARY NOTES

Reprinted from "Journal of Geophysical Research, Vo1. 84, No. C8, August 20, 1978, pp. 5089-5091".

19. KEY WORDS (Continue on peverae alde il necessary end ldontlfy by block number)

1. Temperature gradient

2. VACM (Vector Averaging Current Meter)

3. Temperature Finestructure

20. ABSTRACT (Continue on reverse olde if neceseary and Identify by block number)

Vector averaging current meters have been modified to measure the temperature gradient in addition to current and absolute temperature. The modified instrument measures the temperature difference between sensors spaced vertically $1.74 \mathrm{~m}$ apart (or closer) using thermistors in a Wheatstone bridge circuit. Calibrations provide corrections for drift and static offset resulting in temperature gradient measurements accurate to about $0.5 \mathrm{~m} \mathrm{C} / \mathrm{m}$.

Originally developed to infer vertical velocities, the instrument (Cont. on bac) 
- CU PITY CLASSIFICATION OF THIS PAGE(Whon Data Entered)

has also been successfully used to study mixed layer motions and thickness variations and to investigate temperature fine structure.

SECURITY CLASSIFICATION OF THIS PAGE(Whon Data Entered) 


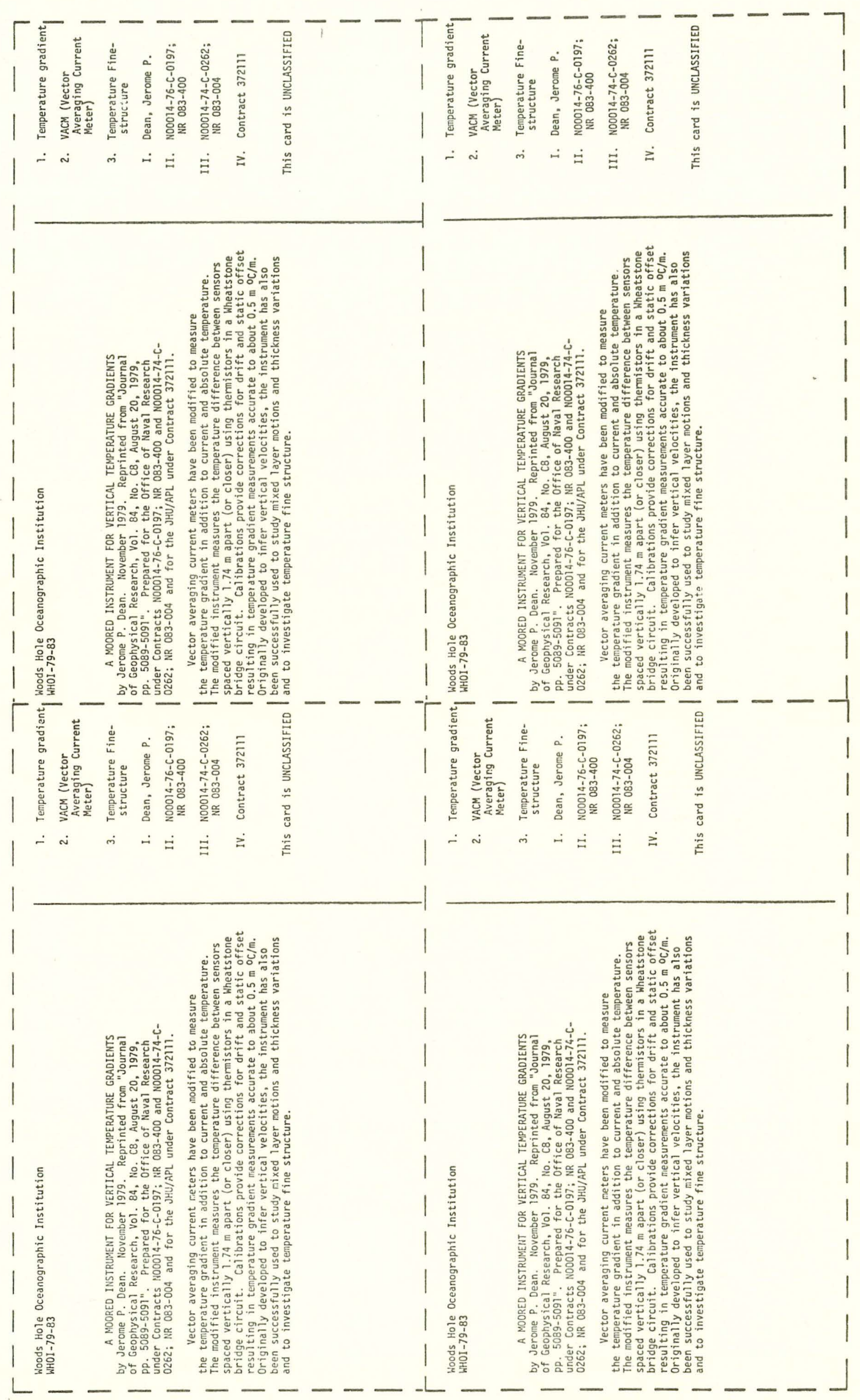

